\title{
English and Communication Skills - International Survey on Employers' Needs in Engineering Education
}

\author{
英語とコミュニケーションカー企業の技術者教育への要望に関する国際比較 \\ Werawan Manakul*1 \\ ウイラワン マナクン
}

\begin{abstract}
日本技術者教育認定機構専務理事の福㠃弘氏は,「日本が発展途上にあったとき, 多くの技術者を 必要としていた.」と述べているが, さらに，「しかし，もうそれほどの技術者を必要としていない. 今必要なのは，量ではなく質である.」と続けている。日本の大学における技術者教育カリキュラム における非技術的な側面における改善の必要性を示すために, 日本, 韓国, 夕イ, ベトナムの企業に 対して, アンケート調査を行った。 その結果, 2つの能力の重要性が浮かび上がった４４国すべて において, 強調されたコミュニケーション能力と, 日本を除く 3 力国で指摘された英語能力である. 本論文は，日本においても英語能力が必要なことを明らかにするとともに，北海道大学大学院工学研

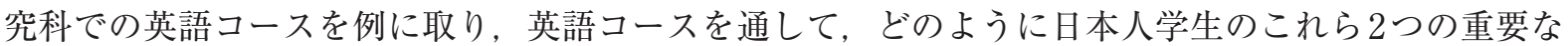
能力，特に英語能力を向上させるかを論じている.
\end{abstract}

キーワード：コミュニケーション力，英語能力，英語による工学系大学院課程

Keywords : Communication Skills, English Ability, Engineering Graduate Program in English

\section{INTRODUCTION}

It is well known that Japanese universities are difficult to enter but easy to graduate. Once students pass the entrance exams, most make little effort to study hard. This is so because of the life time employment tradition that regards fresh graduates as raw materials and university entrance examination as a screening tool. Although the life time employment is becoming more and more a thing of the past, most companies still start their recruitment more than one year in advance of the actual job openings and make job offers one year before the students graduate. Students spend a lot of time finding out about companies and job vacancies. It is not unusual for students to miss a lot of classes during this “job-hunting season”. Companies' disregard of what the students learned at the universities naturally reduces the necessity for students to be serious in their study and at the same time discourages faculty to be serious in their teaching.

The establishment of Japan Accreditation Board for Engineering Education (JABEE) in 1999 has

平成 17 年 10 月 20 日受付

※ 1 Lecturer, Center for Engineering Education Development, Hokkaido University injected life and seriousness into undergraduate engineering education however the graduate education remains untouched. Given the fact that more and more engineering students proceed to the master's program, it is the universities' responsibility to clearly show the differences between undergraduate and graduate education. In other word additional knowledge and skills the students acquired during the two years they spend in the graduate program should stand out.

This paper provides readers with a glimpse of what companies in Japan and the other 3 Asian countries consider important when hiring fresh engineering graduates. Two aspects perceived very important by all countries except Japan are identified and methods to develop these qualifications are recommended.

\section{EMPLOYER SURVEY}

To verify common belief held by most faculty and at the same time learn the real needs of Japanese companies, the author sent out questionnaire to firms that hired engineering graduates of Hokkaido University. Sixty-three companies responded. For comparison and an overview of the emphasis put by companies in other countries, the author conducted 
the same survey but on a smaller scale in Korea (23 companies), Thailand (20) and Vietnam(19). These companies were asked to rank the degree of importance they place when recruiting fresh engineering graduates, from "Not important", "Important", and "Very important" on the following points :

a. University where the applicant received his bachelor's degree

b. University where the applicant received his master's degree

c. Who his supervisor was

d. Grades he obtained in his coursework

e. Research potential through thesis/publication

f. Research potential shown during presentation at conference, etc

g. Recommendation letter h. Result of company's written examination

i. Communication skills

j. Leadership quality

k. Team work quality

1. Self-motivation

m. Creativity

n. Flexibility

o. Sense of responsibility

p. English ability

q. General knowledge

r. License as qualified engineer in relevant field

As can be seen from the content of the questionnaire, no attempt has been made on the course technical contents since companies where questionnaires were sent are of varied engineering fields. The overall survey results are given in Fig. 1 below.

Fig. 1 Degrees of importance placed by companies in Japan, Korea, Thailand and Vietnam when hiring fresh engineering master's degree graduates

c. Who his supervisor was

d. Grades he obtained in his coursework

e. Research potential through publication

f. Research potential through presentation

g. Recommendation letter

63 Japan

a. Which university the candidate received his bachelor's degree

Very important Important

Not important

No answer

\section{1}

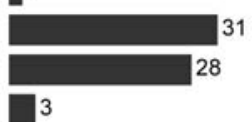

22 Korea

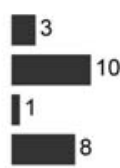

b. Which university the candidate received his master's degree
Very important Important

Not important No answer
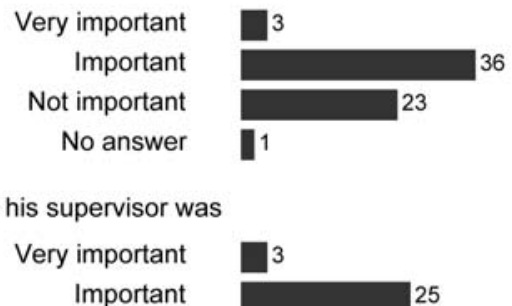

Important

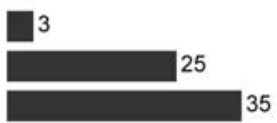

I2

Not important
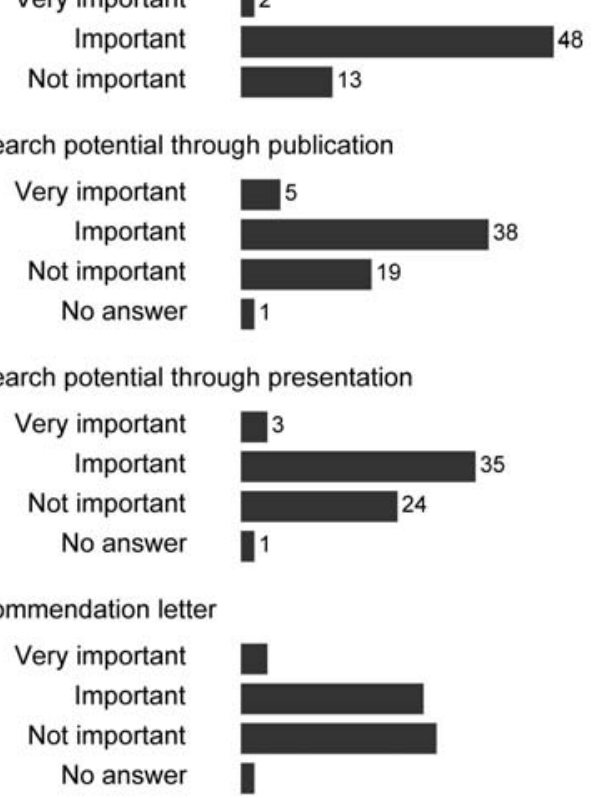

22 Thailand

15 Vietnam
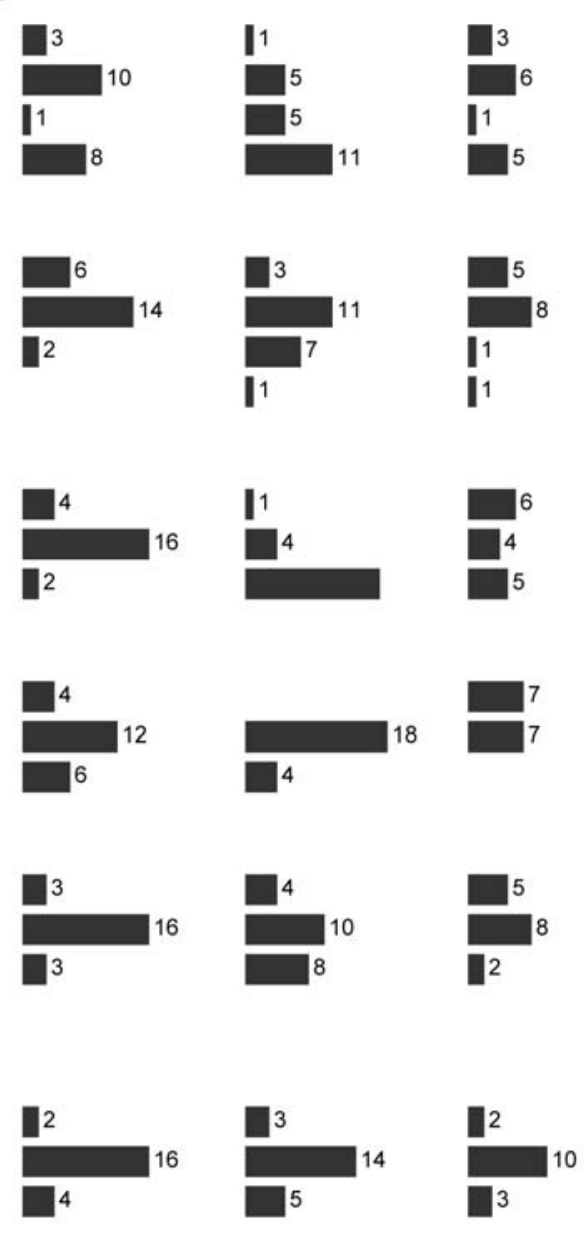
No answer

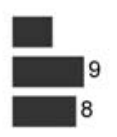

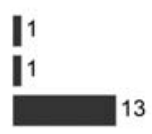


h. Result of company's written examination

Very important
Important

Not important

No answer

i. Communication skills

Very important

Important

Not important

j. Leadership skills

Very important

Important

Not important

No answer

k. Team work quality

Very important

Important

Not important

No answer

I. Self-motivation

Very important

Important

Not important
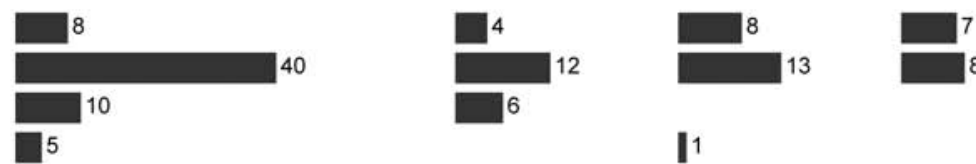

】1
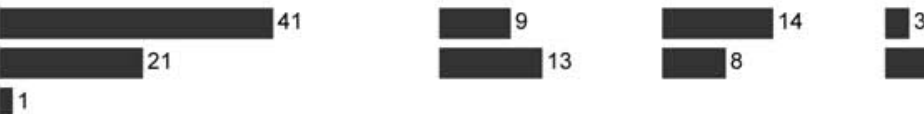

1
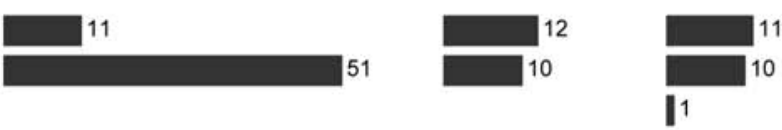

1

11

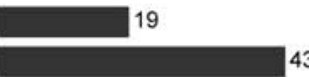

【1
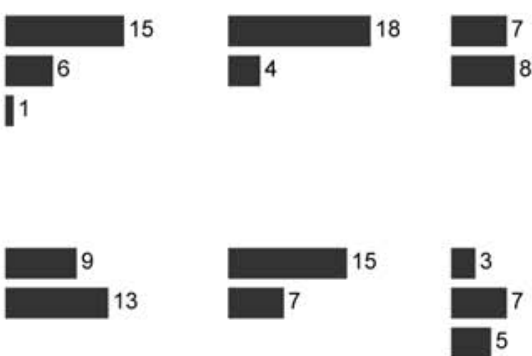

m. Creativity

Very important
Important

Not important

n. Flexibility
Very important Important

Not important
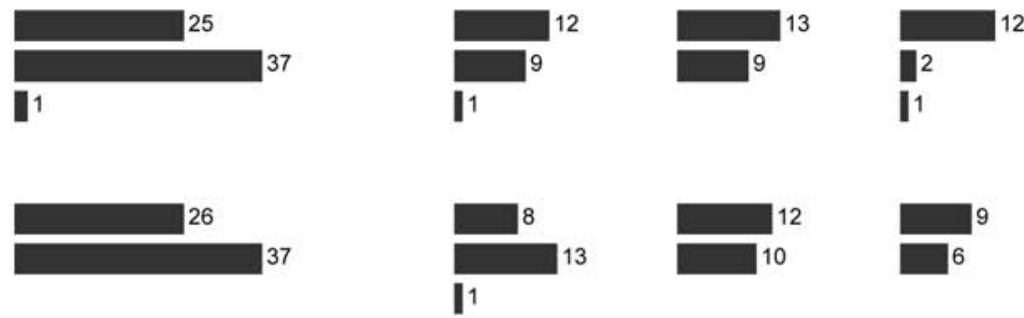

o. Sense of responsibility

Very important

Important

Not important
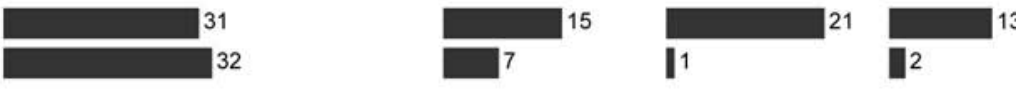

p. English ability

Very important Important

Not important No answer
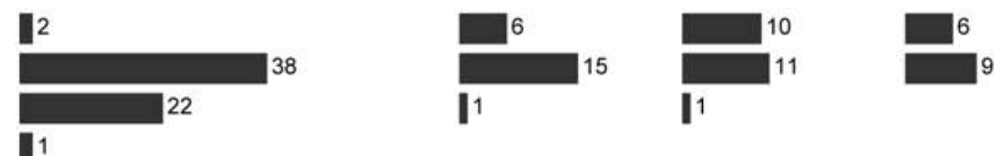

【 1

q. General knowledge

Very important Important

Not important No answer
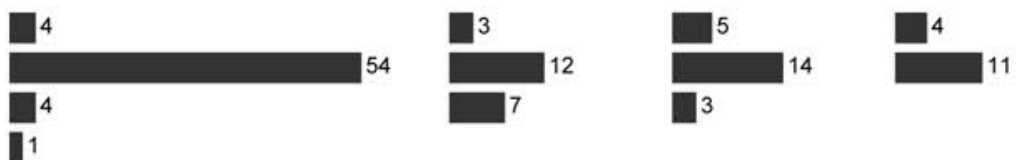

r. License as qualified engineers

Very important
Important
Not important No answer
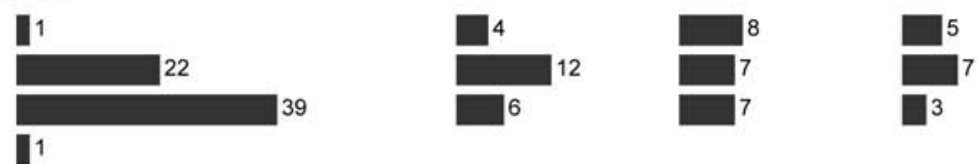

Note : Types of industry/business of companies in Japan and Thailand are varied while those of companies in Korea and Vietnam are construction related. 


\section{INTERPRETATION AND FACTORS CON- TRIBUTING TO THE SURVEY RESULTS}

University name - It is undeniable that the university's name plays a great role in every country. Universities with a long history tend to be highly regarded because their names are familiar and because they started producing graduates into the society early. These alumni scattered in every corner of the country and many rose into prominent positions. As a result job opportunities for graduates from these universities are better. Since the ultimate aim of everyone is getting a good job, universities that provide better job opportunities naturally draw more applicants and increase their reputation. The number of companies that consider which university the applicant graduates from important exceeds those who do not. However a relatively small number considers that fact very important.

Who his supervisor was - Korea leads in this aspect with $91 \%$ of the companies consider who the applicant's academic supervisor was important and very important. This may be due to the strong seniority and personal tie culture of Korea. The figures stand at 23\% and $45 \%$ for the Thai and Japanese companies. It is not because Thailand and Japan do not at all share the similar culture, however both countries have a large number of universities that produce engineering graduates. Each year in Thailand about $13 \%{ }^{1)}$ and in Japan about $19 \%^{2}$ of the undergraduate degrees granted are in engineering.

Grades obtained from university and company's written examination - Over $70 \%$ of the Japanese and Korean companies and all Thai and Vietnamese companies consider the result of their own examination important and very important. In Japan where the focus of examination is on general knowledge assumed to be provided by universities, why do companies still need their own examination? The survey results also reveal a contradicting fact that $80 \%-100 \%$ of companies consider grades important.

Research potential through publications - While 86\% Korean and Vietnamese companies consider publications important, $68 \%$ and $63 \%$ of Japanese and Thai companies think so. The percentages are rather high despite the fact that not all master's graduates have publications other than their thesis and that the companies do not necessarily expect their employees to be responsible in research and development.

Research potential through presentation at confer- ences $-82 \%$ of Korean and $80 \%$ of Vietnamese companies place importance on research potential through presentation while $77 \%$ and $60 \%$ of companies in Thailand and Japan do. Presentation at conferences can be considered somewhat equivalent to an interview since it clearly shows how well a person is organized and how deep his knowledge is. Emphasis on this criterion depends largely on the nature and practice of companies.

Communication skills - Almost all companies in the four countries surveyed place importance to communication skills, leadership skills, teamwork quality, self-motivation, creativity, flexibility and sense of responsibility. Only in 2 categories, namely leadership and motivation, that slightly less than $30 \%$ of Vietnamese companies do not think is important. Vietnam's political background which has yet to become a full democracy may be behind this view.

English ability - All Vietnamese companies surveyed consider English ability important while 95\% of Korean and Thai companies also think the same. On the other hand only $65 \%$ of Japanese companies think so. The low percentage by Japanese companies correlates to the size of companies. $67 \%$ of Japanese companies that returned the questionnaire have more than 1,000 employees. The domestic market is big and although many of these companies have overseas business, only a small fraction of their engineers are required to interact directly in English language. Another reason may be that reliance on imported know-how is low in Japan.

General knowledge - All Vietnamese companies, $92 \%$ and $86 \%$ of Japanese and Thai companies place importance in general knowledge while $69 \%$ of the Korean companies do. There are various ways to look at the situation. The emphasis may come from the observation or experience companies have with their employees with regard to general knowledge or general knowledge itself is not considered important by companies.

License as qualified engineer - $80 \%$ of Vietnamese companies followed by $73 \%$ of Korean, $68 \%$ of Thai and $37 \%$ of Japanese companies place importance on licenses. Again the author would like to think that the size of companies plays a role in this requirement. Like English fluency, some engineers working for a large company may work throughout his life without any need to use English since the work that requires English is done by another group. On the contrary smaller companies are not in a position to have dif- 
ferent employees for different works, employees with more qualifications are therefore preferred.

\section{WHAT DO WE GET FROM THE SURVEY RESULT}

The survey result draws attention to 2 items that have been or becoming increasingly important. They are English ability and communication skills.

\section{1 English ability}

Compared to other Asian countries, Japanese companies are slow to recognize that English is important because they can survive quite comfortably doing business domestically. An increase in the number of FTAs, of Japanese companies taken over by foreign firms, the penetration of foreign firms into the domestic market, etc should serve as a wake-up call that it is time that they too must expand their business into the growing Asian markets.

MEXT realizes the urgent need to prepare Japanese students to face the challenges in the ever increasing international economic competition. As a result an Action Plan to Cultivate "Japanese with English Abilities" was released in 2003. According to the Plan, universities are supposed to educate students so that "On graduating from university, graduates can use English in their work" ${ }^{3)}$. In the case of the Graduate School of Engineering, Hokkaido University, the following actions should be taken :

4. 1. 1 Increase the number of regular courses taught in English

The English Graduate Program in Socio-Environmental Engineering (EGPSEE) offered jointly by 6 Divisions was established in 2000. As of October 2005, 51 master's and doctoral students from 14 countries including 13 from Japan enroll in the program. The program runs parallel to the ordinary Japanese program, in other words courses are supposed to be taught twice, once in English for the English program and again in Japanese for the Japanese program. However since its establishment some course instructors have been teaching their courses in English only and in 2005 one Division offers all of its courses in English only. This brings the total of courses offered in English only to 30\% of the 58 courses currently offered by EGPSEE. All course instructors agree that Japanese students have no problem understanding courses taught in English if such courses are in their own field.

In order to familiarize students with English technical terms and prepare them for graduate courses offered in English, a portion of undergraduate courses should be given in English. In many developing countries where translation of engineering books is not cost effective, university students use English textbooks although the instruction is given in the local language.

\section{1.2 Make use of the seminars regularly held in each laboratory}

A master's student is required to earn a total of 30 credits - 16 from courses within his own Division, 4 from courses in another Division and 10 from a socalled seminar. The way seminar is conducted is not regulated. Most laboratories use it as a venue for $4^{\text {th }}$ year and graduate students, both Japanese and foreign, to present their research progress enabling everyone in the laboratory to learn about each other research, ask questions and give comments. Some laboratories assign students to read a chapter in a book or an article and take turn to present what they have learned from that chapter or article. The duration and frequency of seminar are not regulated either. It can last from an hour to a whole day and can be held weekly, bi-monthly, monthly or occasionally.

Despite the fact that the nature and the conduct of seminar varies, some laboratories are successful in raising the quality of students' English and presentation skills. Unlike lectures, $70 \%$ of which are given separately to students in the Japanese program and those in the English program, seminar is a place where students from both programs attend. This co-attendance creates a good opportunity for the Japanese students to familiarize themselves with English and as a result improve their English skills. While some laboratories have their Japanese students prepare the presentation materials in English but allow them to present in Japanese, some have their students do everything in English.

\section{1. 3 Increase the number of English speaking foreign students}

An attempt should be made to provide engineering education in English so that more English speaking foreign students can enroll. At present except EGPSEE, most foreign students in Hokkaido University are Japanese speaking. Existence of English speaking foreign students will naturally create an environment conducive to improving Japanese students' English ability as is evident in the Socio-Environment Engineering group where EGPSEE belongs. 


\section{1. 4 Recognition of efforts by academic staff}

Having non-Japanese speaking foreign students increases the workload of supervising professors in term of preparation of English materials, explaining the use of experimental equipments (as most equipment manuals are in Japanese), etc. As for course instructors, besides preparing English teaching materials and handouts, the teaching time becomes twice if the course is offered in both Japanese and English. In the case that the course is offered in English only, course instructors face another problem - getting Japanese students with different academic background to follow the course. Considering that these efforts are made to create an international atmosphere in order to enhance the English ability of Japanese students, some kind of recognition should be given to the concerned academic staff. At Yonsei University, Korea, course instructors who offer their courses in English receive additional allowance for their efforts.

\section{2 Communication Skills}

According to the survey result presented in Fig. 1, almost all companies in all the countries surveyed consider the communication skills very important. One of the major determinants of life satisfaction, personal effectiveness and success in work is the skill with which we are able to relate to others. The development and improvement of communication skills is a lifelong undertaking but one which can be taught and enhanced. The management field has long recognized this concept and included several courses related to communication skills in their curriculum.

The current engineering education curriculum of both the Japanese program and EGPSEE do not include courses that deal with these aspects. The university should consider including a course or seminar on communication skills and a Project-Based Learning program in its graduate engineering curriculum. A Project-Based Learning program will serve as a venue for students to exercise what they gained from the course/seminar on communication skills. The PBL program may include joint projects between university and companies, among students from different fields especially those from the English program. Interacting with people from different backgrounds and cultures provides the best opportunity for students to improve their communication skills.

\section{CONCLUSION}

It is clear from the survey result that English abil- ity and communication skills are two key items to improve the quality of engineering graduates in Japan. In this global economy where companies do business anywhere and anytime, engineers should be able to grasp the latest news and information by themselves rather than having to wait for the translation. They should be able to analyze and deal with the situation promptly.

The existence of an English program creates an opportunity for Japanese students to directly communicate with people of different cultures. It makes teaching, research presentation and discussion in English in a Japanese university a normal thing.

Although the recommendations given in 4.1 and 4. 2 above derived from the present situation at Hokkaido University, they can be applied to other universities since the situation in other Japanese universities are similar.

\section{ACKNOWLEDGEMENT}

The author is grateful to the following persons who helped carry out the employer's survey in their respective country - Professor Ha-Won Song of Yonsei University, Korea, Mrs Chantana Chomworakul of Premier Group Co., Ltd. Thailand and Mrs Pham Thi Viet Hoa of the Vietnam Institute for Building Science and Technology. She is indebted to Prof Ueda Tamon whose valuable comments helped reshape this paper.

\section{References}

1 ) Study Report of Public Universities 2000, Ministry of University Affairs, Bangkok, Thailand, 2000.

2) Science and Engineering Indicators 2000, http : //www.nsf.gov/statistics/seind04/c2/c2s5.htm

3 ) Action Plan to Cultivate Japanese with English ability 2003, http ://www.mext.go.jp/english/ topics/03072801.htm

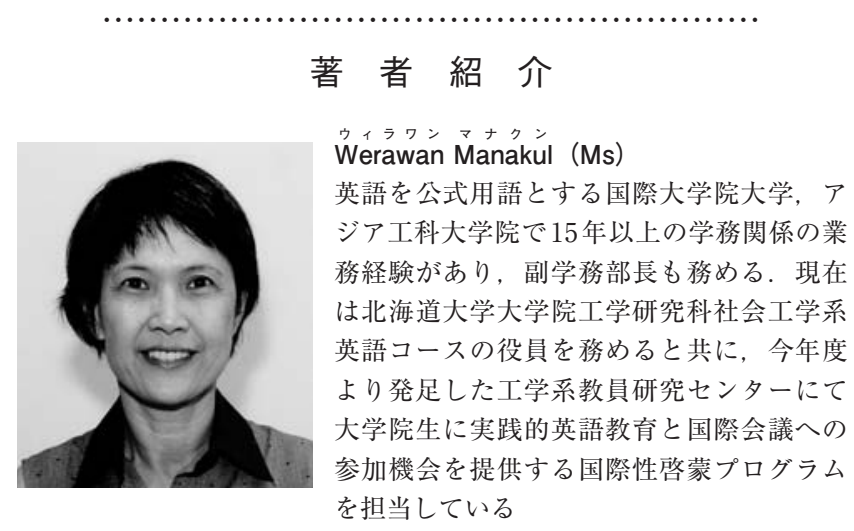

